\title{
The First Metal Complexes of 4,6-diamino-1-hydro-5-hydroxy-pyrimidine-2-thione: Preparation, Physical and Spectroscopic Studies, and Preliminary Antimicrobial Properties
}

\author{
Sahar I. Mostafa, ${ }^{1}$ Constantina Papatriantafyllopoulou, ${ }^{2}$ Spyros P. Perlepes, ${ }^{2}$ and Nick Hadjiliadis ${ }^{3}$ \\ ${ }^{1}$ Chemistry Department, Faculty of Science, Mansoura University, 35516 Mansoura, Egypt \\ ${ }^{2}$ Department of Chemistry, University of Patras, 26504 Patras, Greece \\ ${ }^{3}$ Laboratory of Inorganic and General Chemistry, Department of Chemistry, \\ University of Ioannina, 45110 Ioannina, Greece
}

Correspondence should be addressed to Nick Hadjiliadis, nhadjis@uoi.gr

Received 2 June 2008; Revised 10 October 2008; Accepted 14 December 2008

Recommended by Ian Butler

The new complexes $\left[\mathrm{M}_{2} \mathrm{O}_{5} \mathrm{~L}_{2}\left(\mathrm{H}_{2} \mathrm{O}\right)_{2}\right] \cdot \mathrm{H}_{2} \mathrm{O}(\mathrm{M}=\mathrm{Mo}, \mathbf{1} ; \mathrm{M}=\mathrm{W}, 2),\left[\mathrm{RuL}_{2}\left(\mathrm{H}_{2} \mathrm{O}\right)_{2}\right] \cdot \mathrm{H}_{2} \mathrm{O}(3)$, $\left[\mathrm{ML}_{3}\right] \cdot x \mathrm{H}_{2} \mathrm{O}(\mathrm{M}=$ $\mathrm{Rh}, x=2,4 ; \mathrm{M}=\mathrm{Ir}, x=1,5),\left[\mathrm{RhL}_{2}\left(\mathrm{PPh}_{3}\right)_{2}\right]\left(\mathrm{ClO}_{4}\right) \cdot 2 \mathrm{H}_{2} \mathrm{O}(\mathbf{6}),\left[\mathrm{PdL}_{2}\right] \cdot 2 \mathrm{H}_{2} \mathrm{O}(\mathbf{7}),[\mathrm{PdL}(\mathrm{phen})] \mathrm{Cl} \cdot \mathrm{H}_{2} \mathrm{O}(\mathbf{8})$, $\left[\mathrm{ReOL}_{2}\left(\mathrm{PPh}_{3}\right)\right] \mathrm{Cl}(\mathbf{9})$ and $\left[\mathrm{UO}_{2} \mathrm{~L}_{2}\right](\mathbf{1 0})$ are reported, where $\mathrm{LH}$ is 4,6-diamino-1-hydro-5-hydroxy-pyrimidine-2-thione. The complexes were characterized by elemental analyses, physical techniques (molar conductivity, room-temperature magnetic susceptibility), and spectroscopic (IR, Raman, UV/VIS/ligand field, NMR, mass) methods. The ligand $\mathrm{L}^{-}$is in its thione form and behaves as a bidentate chelate with the deprotonated (hydroxyl) oxygen and the nitrogen of one amino group as donor atoms. Oxobridged dinuclear $(1,2)$ and various mononuclear $(3-10)$ structures are assigned for the complexes in the solid state. The metal ion coordination geometries are octahedral $(\mathbf{1}-\mathbf{6 , 9}, \mathbf{9})$ or square planar $(\mathbf{7}, \mathbf{8})$. The free ligand LH and complexes 1, 4, 7, and 8 were assayed in vitro for antimicrobial activity against two bacterial and two fungal cultures.

Copyright (C) 2008 Sahar I. Mostafa et al. This is an open access article distributed under the Creative Commons Attribution License, which permits unrestricted use, distribution, and reproduction in any medium, provided the original work is properly cited.

\section{INTRODUCTION}

2-Mercaptopyrimidine nucleotides have been detected in Escherichia Coli sRNA and yeast tRNA; it has been found that they inhibit the synthesis of tRNA, thus acting as antitumour and antithyroid agents [1]. A similar inhibitory effect has been observed for pyrimidine-2-thione (I in Scheme 1) and its derivatives, which also show pronounced in vitro bacteriostatic activity [1]. Metal complexes of pyrimidine2-thione or its pyrimidine-2-thiol tautomeric form $[1,2]$ and its amino [2,3] or hydroxy [4-6] derivatives have been prepared and studied (for representative ligands see Scheme 1). Such complexes exhibit rich structural chemistry, and interesting thermal, magnetic, sorptive, and biological properties. However, the coordination chemistry of ligands based on the 2-mercaptopyrimidine moiety and containing both hydroxy and amino substituents on the pyrimidine ring is completely unkown.

We now describe here the preparation and characterization of the first metal complexes of 4,6-diamino-5hydroxy-2-mercaptopyrimidine ( $\mathrm{LH}$, Scheme 2). We also report the antimicrobial activity of the free ligand and four representative complexes against two bacteria and two fungi. This work can be considered as a continuation of our interest on the coordination chemistry of derivatized pyrimidines [7].

\section{EXPERIMENTS}

All reagents were purchased from Merck and Alfa/Aesar. $\mathrm{Na}_{2}\left[\mathrm{IrCl}_{6}\right]$ is commercially available. $\left[\mathrm{PdCl}_{2}\right.$ (phen)] was prepared by the reaction of $\mathrm{K}_{2}\left[\mathrm{PdCl}_{4}\right]$ and 1,10-phenanthroline 
<smiles>S=c1nccc[nH]1</smiles><smiles>Nc1ccnc(S)n1</smiles><smiles>Nc1cc(N)[nH]c(=S)n1</smiles>

II<smiles>Oc1ccncn1</smiles>

III<smiles>Oc1ncccn1</smiles>

IV<smiles>Nc1nc(S)nc(N)c1O</smiles>

Thiol form

Scheme 2: 4,6-diamino-5-hydroxy-2-mercaptopyrimidine (LH).

in $\mathrm{H}_{2} \mathrm{O} / \mathrm{EtOH}$. $\left[\mathrm{ReOCl}\left(\mathrm{PPh}_{3}\right)_{2}\right]$ was synthesized as previously reported [8]. DMSO used in conductivity measurements was dried over molecular sieves. The DMSO$\mathrm{d}_{6}$ protons $(\mathrm{NMR})$ were referenced using TMS. Warning: perchlorate salts are potentially explosive; such compounds should be used in small quantities and treated with utmost care at all times. Elemental analyses $(\mathrm{C}, \mathrm{H}, \mathrm{N}, \mathrm{S})$ were performed by the University of Ioannina (Greece) Microanalytical Unit with an EA 1108 Carlo-Erba analyzer. The water content of the complexes was also confirmed by TG/DTG measurements performed on a Shimadzu Thermogravimetric Analyzer TGA-50. IR spectra were recorded on a Matson 5000 FT-IR spectrometer with samples prepared as $\mathrm{KBr}$ pellets. Far-IR spectra were recorded on a Bruker IFS $113 \mathrm{v}$ FT spectrometer with samples prepared as polyethylene pellets. FT Raman data were collected on a Bruker IFS $66 \mathrm{v}$ interferometer with an FRA 106 Raman module, a CW Nd: YAG laser source, and a liquid nitrogen-cooled Ge detector. Solution electronic spectra were recorded using a Unicam $\mathrm{UV}_{2-100}$ spectrophotometer. Solid-state (diffuse reflectance, DRS) electronic spectra in the 300-800 nm range were recorded on a Varian Cary 3 spectrometer equipped

with an integration sphere. ${ }^{1} \mathrm{H}$ NMR studies were performed on a Varian Gemini WM-200 spectrometer. ${ }^{31} \mathrm{P}\left\{{ }^{1} \mathrm{H}\right\}$ NMR spectra were recorded with a Varian Mercury equipment [ref. 85\% $\mathrm{H}_{3} \mathrm{PO}_{4}$ (ext.)] . Mass spectra were recorded on a Matson 5988 MS spectrometer. Conductivity measurements were carried out at room temperature on a YSI, model 32 conductivity bridge using $10^{-3} \mathrm{M}$ solutions. Room temperature magnetic susceptibility measurements were performed using a Johnson Matthey magnetic balance standardized with $\mathrm{HgCo}(\mathrm{NCS})_{4}$; diamagnetic corrections were estimated using Pascal's constants.

\subsection{Preparation of the complexes}

$\left[\mathrm{Mo}_{2} \mathrm{O}_{5} \mathrm{~L}_{2}\left(\mathrm{H}_{2} \mathrm{O}\right)_{2}\right] \cdot \mathrm{H}_{2} \mathrm{O}(1)$

An aqueous solution $\left(5 \mathrm{~cm}^{3}\right)$ of $\left(\mathrm{NH}_{4}\right)_{2}\left[\mathrm{MoO}_{4}\right](0.24 \mathrm{~g}$, $1.0 \mathrm{mmol})$ was added to a solution of $\mathrm{LH}(0.16 \mathrm{~g}, 1.0 \mathrm{mmol})$ in $\mathrm{EtOH}\left(25 \mathrm{~cm}^{3}\right)$. The obtained slurry was heated and the resulting orange solution was refluxed for 4 hours, during which time an orange precipitate is formed. The solid was collected by filtration, washed with ethanol $\left(2 \mathrm{~cm}^{3}\right)$ and diethyl ether $\left(2 \times 5 \mathrm{~cm}^{3}\right)$ and dried in vacuo. The yield was $35 \%$ (based on the metal). Elemental analytical calculation for $\mathrm{C}_{8} \mathrm{H}_{16} \mathrm{~N}_{8} \mathrm{O}_{10} \mathrm{~S}_{2}$ Mo: C, $15.00 ; \mathrm{H}, 2.50 ; \mathrm{N}, 17.50 ; \mathrm{S}, 10.00 \%$ found that $\mathrm{C}, 14.98 ; \mathrm{H}, 2.82 ; \mathrm{N}, 17.51 ; \mathrm{S}, 9.87 \% ; \Lambda_{\mathrm{M}}(\mathrm{DMSO})$ : $3 \mathrm{~S} \mathrm{~cm}^{2} \mathrm{~mol}^{-1}$.

$\left[\mathrm{W}_{2} \mathrm{O}_{5} \mathrm{~L}_{2}\left(\mathrm{H}_{2} \mathrm{O}\right)_{2}\right] \cdot \mathrm{H}_{2} \mathrm{O}(2)$

Using $\left(\mathrm{NH}_{4}\right)_{2}\left[\mathrm{WO}_{4}\right]$ and following exactly the same procedure as that described for complex $\mathbf{1}$, a bright yellow material was isolated. The yield was $50 \%$ (based on the metal). Elemental analytical calculation for $\mathrm{C}_{8} \mathrm{H}_{16} \mathrm{~N}_{8} \mathrm{O}_{10} \mathrm{~S}_{2} \mathrm{~W}$ : C, $11.77 ; \mathrm{H}, 1.96 ; \mathrm{N}, 13.73 ; \mathrm{S}, 7.85 \%$ found that $\mathrm{C}, 11.62 ; \mathrm{H}$, $1.90 ; \mathrm{N}, 13.77 ; \mathrm{S}, 7.95 \% ; \Lambda_{\mathrm{M}}(\mathrm{DMSO}): 2 \mathrm{~S} \mathrm{~cm}^{2} \mathrm{~mol}^{-1}$. 


\section{$\left[\mathrm{RuL}_{2}\left(\mathrm{H}_{2} \mathrm{O}\right)_{2}\right] \cdot \mathrm{H}_{2} \mathrm{O}(3)$}

Solid $\mathrm{RuCl}_{3} \cdot 3 \mathrm{H}_{2} \mathrm{O}(0.12 \mathrm{~g}, 0.46 \mathrm{mmol})$ was added to a solution of $\mathrm{NaO}_{2} \mathrm{CMe}(0.62 \mathrm{~g}, 7.5 \mathrm{mmol})$ in water $\left(30 \mathrm{~cm}^{3}\right)$. Solid LH (0.24 g, $1.5 \mathrm{mmol})$ was then added and the resultant reaction mixture was refluxed for 12 hours. The deep brown solid formed was collected by filtration while the reaction mixture was hot, washed with hot water, and dried in vacuo. The yield was 30\% (based on the metal). Elemental analytical calculation for $\mathrm{C}_{8} \mathrm{H}_{16} \mathrm{~N}_{8} \mathrm{O}_{5} \mathrm{~S}_{2} \mathrm{Ru}$ : C, 20.46; $\mathrm{H}, 3.41 ; \mathrm{N}, 23.88$; S, $13.64 \%$ found that C, 20.32; H, 3.05; N, 23.57; S, $13.21 \%$; $\Lambda_{\mathrm{M}}(\mathrm{DMSO}): 1 \mathrm{~S} \mathrm{~cm}^{2} \mathrm{~mol}^{-1}$.

\section{$\left[R h L_{3}\right] \cdot 2 \mathrm{H}_{2} \mathrm{O}(4)$}

Using $\mathrm{RhCl}_{3} \cdot 3 \mathrm{H}_{2} \mathrm{O}$ and following the same procedure as that described for complex 3 , a reddish brown material was isolated. The yield was $60 \%$ (based on the metal). Elemental analytical calculation for $\mathrm{C}_{12} \mathrm{H}_{19} \mathrm{~N}_{12} \mathrm{O}_{5} \mathrm{~S}_{3} \mathrm{Rh}$ : C, 23.61; $\mathrm{H}$, $3.12 ; \mathrm{N}, 27.55 ; \mathrm{S}, 15.74 \%$ found that $\mathrm{C}, 23.73 ; \mathrm{H}, 3.11 ; \mathrm{N}$, 26.36; S, $14.98 \% ; \Lambda_{\mathrm{M}}(\mathrm{DMSO}): 6 \mathrm{~S} \mathrm{~cm}^{2} \mathrm{~mol}^{-1}$.

\section{$\left[I r L_{3}\right] \cdot \mathrm{H}_{2} \mathrm{O}(5)$}

Using $\mathrm{Na}_{2}\left[\mathrm{IrCl}_{6}\right]$ and following the same procedure as that described for complex 3, a yellow solid was isolated. The yield was $25 \%$ (based on the metal). Elemental analytical calculation for $\mathrm{C}_{12} \mathrm{H}_{17} \mathrm{~N}_{12} \mathrm{O}_{4} \mathrm{~S}_{3} \mathrm{Ir}$ : C, 21.14; H, 2.50; N, 24.66; S, $14.09 \%$ found that C, 21.33; H, 2.64; N, 24.75; S, 13.85\%; $\Lambda_{\mathrm{M}}(\mathrm{DMSO}): 5 \mathrm{~S} \mathrm{~cm}^{2} \mathrm{~mol}^{-1}$.

$$
\left[\mathrm{RhL}_{2}\left(\mathrm{PPh}_{3}\right)_{2}\right]\left(\mathrm{ClO}_{4}\right) \cdot 2 \mathrm{H}_{2} \mathrm{O}(6)
$$

A hot ethanolic solution $\left(20 \mathrm{~cm}^{3}\right)$ of $\mathrm{LH}(0.25 \mathrm{~g}, 1.6 \mathrm{mmol})$ was added to a solution of $\mathrm{RhCl}_{3} \cdot 3 \mathrm{H}_{2} \mathrm{O}(0.21 \mathrm{~g}, 0.8 \mathrm{mmol})$ in $6 \mathrm{M} \mathrm{HClO}_{4}\left(15 \mathrm{~cm}^{3}\right)$. The resultant orange solution was refluxed for 4 hours and to this was added a solution of $\mathrm{PPh}_{3}(0.43 \mathrm{~g}, 1.6 \mathrm{mmol})$ in hot ethanol $\left(15 \mathrm{~cm}^{3}\right)$. The new solution was refluxed for a further 3 hours and filtered, and its volume decreased in vacuo to give a red-brown solid. The solid was collected by filtration, washed with hot water (2 $\mathrm{x} 2 \mathrm{~mL})$ and hot ethanol $\left(2 \times 3 \mathrm{~cm}^{3}\right)$, and dried in vacuo. The yield was 25\% (based on the metal). Elemental analytical calculation for $\mathrm{C}_{44} \mathrm{CIH}_{44} \mathrm{~N}_{8} \mathrm{O}_{8} \mathrm{~S}_{2} \mathrm{P}_{2} \mathrm{Rh}$ : C, 49.05; H, 4.09; N, $10.41 ; \mathrm{S}, 3.30 \%$ found that $\mathrm{C}, 48.79 ; \mathrm{H}, 4.09 ; \mathrm{N}, 10.44 ; \mathrm{S}$, $3.46 \% ; \Lambda_{\mathrm{M}}(\mathrm{DMSO}): 48 \mathrm{~S} \mathrm{~cm}^{2} \mathrm{~mol}^{-1}$.

\section{$\left[\mathrm{PdL}_{2}\right] \cdot 2 \mathrm{H}_{2} \mathrm{O}(7)$}

To a stirred slurry of LH $(0.16 \mathrm{~g}, 1.0 \mathrm{mmol})$ in methanol $\left(15 \mathrm{~cm}^{3}\right)$ was added an aqueous solution $\left(15 \mathrm{~cm}^{3}\right)$ of $\mathrm{K}_{2}\left[\mathrm{PdCl}_{4}\right](0.16 \mathrm{~g}, 0.5 \mathrm{mmol})$. The resulting suspension was stirred at $40^{\circ} \mathrm{C}$ for 60 hours and the brown solid formed was collected by filtration, washed with water $\left(5 \times 3 \mathrm{~cm}^{3}\right)$ and cold methanol $\left(2 \times 5 \mathrm{~cm}^{3}\right)$, and dried in air. The yield (based on the metal) was 50\%. Elemental analytical calculation for $\mathrm{C}_{8} \mathrm{H}_{14} \mathrm{~N}_{8} \mathrm{O}_{4} \mathrm{~S}_{2} \mathrm{Pd}$ : C,21.03; $\mathrm{H}, 3.07 ; \mathrm{N}, 24.54$; S, $14.02 \%$ found that C, $21.23 ; \mathrm{H}, 3.22 ; \mathrm{N}, 24.85 ; \mathrm{S}, 14.21 \%$; $\Lambda_{\mathrm{M}}(\mathrm{DMSO}): 9 \mathrm{~S} \mathrm{~cm}^{2} \mathrm{~mol}^{-1}$.

\section{$[\mathrm{PdL}$ (phen) $] \mathrm{Cl} \cdot \mathrm{H}_{2} \mathrm{O}(8)$}

To a stirred yellow slurry of $\left[\mathrm{PdCl}_{2}\right.$ (phen) $]$ (0.18g, $0.5 \mathrm{mmol})$ in a methanol/benzene solvent mixture $\left(15 \mathrm{~cm}^{3}\right.$, $3: 2 \mathrm{v} / \mathrm{v})$ was added a solution of $\mathrm{KOH}(0.055 \mathrm{~g}, 1.0 \mathrm{mmol})$ in methanol $\left(15 \mathrm{~cm}^{3}\right)$. Solid $\mathrm{LH}(0.08 \mathrm{~g}, 0.5 \mathrm{mmol})$ was added to the reaction mixture which soon dissolved. The solution was filtered and stirred for 48 hours at room temperature. During this time, a brown precipitate formed which was collected by filtration, washed with water $\left(1 \mathrm{~cm}^{3}\right)$ and methanol $\left(2 \times 3 \mathrm{~cm}^{3}\right)$, and dried in air. The yield was $40 \%$ (based on the ligand). Elemental analytical calculation for $\mathrm{C}_{8} \mathrm{H}_{14} \mathrm{~N}_{8} \mathrm{O}_{4} \mathrm{~S}_{2} \mathrm{Pd}$ : C, 21.03; H, 3.07; N, 24.54; S, $14.02 \%$ found that $\mathrm{C}, 21.23 ; \mathrm{H}, 3.22 ; \mathrm{N}, 24.85 ; \mathrm{S}, 14.21 \%$; $\Lambda_{\mathrm{M}}(\mathrm{DMSO}): 77 \mathrm{~S} \mathrm{~cm}^{2} \mathrm{~mol}^{-1}$.

\section{$\left[\mathrm{ReOL}_{2}\left(\mathrm{PPh}_{3}\right)\right] \mathrm{Cl}(9)$}

To a stirred slurry of $\left[\mathrm{ReOCl}_{3}\left(\mathrm{PPh}_{3}\right)_{2}\right](0.25 \mathrm{~g}, 0.2 \mathrm{mmol})$ in ethanol $\left(30 \mathrm{~cm}^{3}\right)$ was added solid LH $(0.057 \mathrm{~g}, 0.4 \mathrm{mmol})$. The solid soon dissolved and stirred at $40^{\circ} \mathrm{C}$ for 5 hours. The brown solution deposited a brown microcrystalline solid which was collected by filtration, washed with ethanol $\left(3 \times 3 \mathrm{~cm}^{3}\right)$, and dried in vacuo. The yield was $65 \%$ (based on the metal). Elemental analytical calculation for $\mathrm{C}_{26} \mathrm{CIH}_{25} \mathrm{~N}_{8} \mathrm{O}_{3} \mathrm{~S}_{2}$ Re: C, 38.34; H, 3.07; N, 13.76; S, 7.86\% found that C, $38.37 ; \mathrm{H}, 3.11 ; \mathrm{N}, 13.87 ; \mathrm{S}, 7.98 \% ; \Lambda_{\mathrm{M}}(\mathrm{DMSO})$ : $46 \mathrm{~S} \mathrm{~cm}^{2} \mathrm{~mol}^{-1}$.

\section{$\left[\mathrm{UO}_{2} \mathrm{~L}_{2}\right](10)$}

Solid LH (0.08 g, $0.5 \mathrm{mmol})$ was added to a stirred solution of $\left[\mathrm{UO}_{2}\left(\mathrm{NO}_{3}\right)_{2}\right] \cdot 6 \mathrm{H}_{2} \mathrm{O}(0.25 \mathrm{~g}, 0.5 \mathrm{mmol})$ in methanol $\left(10 \mathrm{~cm}^{3}\right)$. The solid soon dissolved. The resultant yellow solution was filtered and refluxed for 4 hours, during which time a red microcrystalline solid was precipitated. The product was collected by filtration, washed with methanol $\left(5 \mathrm{~cm}^{3}\right)$ and diethyl ether $\left(2 \times 5 \mathrm{~cm}^{3}\right)$, and dried in vacuo. The yield was 55\% (based on the metal). Elemental analytical calculation for $\mathrm{C}_{8} \mathrm{H}_{10} \mathrm{~N}_{8} \mathrm{O}_{4} \mathrm{~S}_{2} \mathrm{U}$ : C, 16.44; $\mathrm{H}, 1.71 ; \mathrm{N}, 19.18$; S, $10.96 \%$ found that C, 16.35; H, 2.02; N, 18.98; S, 10.86\%; $\Lambda_{\mathrm{M}}(\mathrm{DMSO}): 11 \mathrm{~S} \mathrm{~cm}^{2} \mathrm{~mol}^{-1}$.

\subsection{Antimicrobial activity}

The bacterial strains ( $S$. aureus and $P$. aeruginosa) were grown in Nutrient agar slants and the fungal strains $(A$. niger and C. albicans) were grown in Sabouraud dextrose agar slants. The viable bacterial cells were swabbed onto Nutrient agar plates, while the fungal spores onto Sabouraud dextrose agar plates. The free ligand and complexes 1, 4, 7 were dissolved in DMSO, while complex 8 was dissolved in $\mathrm{H}_{2} \mathrm{O}$ with 10, 20, 50 , and $100 \mathrm{mg} / \mathrm{mL}$ concentrations. The blank was DMSO in saline buffer. The bacterial and fungal plates were incubated for 36 and 72 hours, respectively, and the activity of the compounds was estimated by measuring the diameter of the inhibition zone (the affected zone by the compounds) around the respective zone (the normal place in the agar). The incubation temperature was $27 \pm 0.5^{\circ} \mathrm{C}$. 


\section{RESULTS AND DISCUSSION}

\subsection{Synthetic comments and physical characterization}

The preparative reactions for selected complexes can be represented by the stoichiometric equations (1)-(7); no attempts were made to optimize the yields,

$$
\begin{aligned}
& 2\left(\mathrm{NH}_{4}\right)_{2}\left[\mathrm{MO}_{4}\right]+2 \mathrm{LH} \\
& \underset{\mathrm{T}}{\stackrel{\mathrm{EtOH} / \mathrm{H}_{2} \mathrm{O}}{\longrightarrow}}\left[\mathrm{M}_{2} \mathrm{O}_{5} \mathrm{~L}_{2}\left(\mathrm{H}_{2} \mathrm{O}\right)_{2}\right]+4 \mathrm{NH}_{3}+\mathrm{H}_{2} \mathrm{O} \\
& \mathrm{M}=\mathrm{Mo}(\mathbf{1}), \mathrm{W}(\mathbf{2}), \\
& \mathrm{RhCl}_{3} \cdot 3 \mathrm{H}_{2} \mathrm{O}+3 \mathrm{LH}+3 \mathrm{NaO}_{2} \mathrm{CMe} \\
& \underset{\mathrm{T}}{\stackrel{\mathrm{H}_{2} \mathrm{O}}{\longrightarrow}}\left[\mathrm{RhL}_{3}\right](4)+3 \mathrm{NaCl}+3 \mathrm{MeCO}_{2} \mathrm{H}+3 \mathrm{H}_{2} \mathrm{O}, \\
& \mathrm{RhCl}_{3} \cdot 3 \mathrm{H}_{2} \mathrm{O}+2 \mathrm{LH}+2 \mathrm{PPh}_{2}+\mathrm{HCIO}_{4} \\
& \underset{\mathrm{T}}{\stackrel{\mathrm{EtOH} / \mathrm{H}_{2} \mathrm{O}}{\longrightarrow}}\left[\mathrm{RhL}_{2}\left(\mathrm{PPh}_{3}\right)_{2}\right]\left(\mathrm{ClO}_{4}\right)(6)+3 \mathrm{HCl}+3 \mathrm{H}_{2} \mathrm{O}, \\
& \mathrm{K}_{2}\left[\mathrm{PdCl}_{4}\right]+2 \mathrm{LH} \\
& \stackrel{\mathrm{MeOH} / \mathrm{H}_{2} \mathrm{O}}{\longrightarrow}\left[\mathrm{PdL}_{2}\right](7)+2 \mathrm{KCl}+2 \mathrm{HCl}, \\
& {\left[\mathrm{PdCl}_{2}(\text { phen })\right]+\mathrm{LH}+\mathrm{KOH}} \\
& \stackrel{\text { MeOH/benzene }}{\longrightarrow}[\mathrm{PdL}(\text { phen })] \mathrm{Cl}(\mathbf{8})+\mathrm{KCl}+\mathrm{H}_{2} \mathrm{O}, \\
& {\left[\mathrm{ReOCl}_{3}\left(\mathrm{PPh}_{3}\right)_{2}\right]+2 \mathrm{LH}} \\
& \stackrel{\mathrm{EtOH}}{\longrightarrow}\left[\mathrm{ReOl}_{2}\left(\mathrm{PPh}_{3}\right)_{2}\right] \mathrm{Cl}(\mathbf{9})+2 \mathrm{HCl}+\mathrm{PPh}_{3}, \\
& {\left[\mathrm{UO}_{2}\left(\mathrm{NO}_{3}\right)_{2}\right] \cdot 6 \mathrm{H}_{2} \mathrm{O}+2 \mathrm{LH}} \\
& \underset{\mathrm{T}}{\stackrel{\mathrm{MeOH}}{\longrightarrow}}\left[\mathrm{UO}_{2} \mathrm{~L}_{2}\right](\mathbf{1 0})+2 \mathrm{HNO}_{3}+6 \mathrm{H}_{2} \mathrm{O} \text {. }
\end{aligned}
$$

The metal is reduced $\left(\mathrm{Ru}^{\mathrm{III}} \rightarrow \mathrm{Ru}^{\mathrm{II}}, \mathrm{Ir}^{\mathrm{IV}} \rightarrow \mathrm{Ir}^{\mathrm{III}}\right)$ during the preparation of complexes $\mathbf{3}$ and $\mathbf{5}$ although the reactions are performed in air. The redox reaction may be facilitated by the reducing character of LH, the products from the oxidation of the ligand remaining in the solution. Thus, LH possibly plays two roles in the reactions, that is, the role of the ligand and that of the reducing agent. It is well known that $\mathrm{Ru}(\mathrm{III})$ can undergo reduction reactions and that the $\left[\mathrm{Ir}^{\mathrm{IV}} \mathrm{Cl}_{6}\right]^{2-}$ ion is a convenient oneelectron oxidant [9]. The use of a base $(\mathrm{KOH})$ in the preparation of $\mathbf{8}$ is necessary to obtain the complex in pure form; otherwise, the produced aqueous $\mathrm{HCl}$ decomposes the compound.

Complexes 1-5, 7 and $\mathbf{1 0}$ are nonelectrolytes in DMSO [10]. Complexes 7 and 10 exhibit slightly increased molar conductivity values in DMSO. Since DMSO is a good donor solvent, this may be due to the partial displacement of one $\mathrm{L}^{-}$ligand by two DMSO molecules. Assuming an equilibrium between the neutral and the resulting cationic complex, this displacement changes the electrolyte type of the compound explaining the increased $\Lambda_{M}$ value [10]. From the molar conductivities in DMSO (complexes 6 and 9) and DMF (complex 8), it is concluded that compounds
6, 8, and 9 behave as $1: 1$ electrolytes, supporting their ionic formulation [10]. All the complexes are diamagnetic, as expected [9]. It should be mentioned at this point that the $\pi$ bonding in the $\left\{\operatorname{Re}^{\mathrm{V}}=\mathrm{O}\right\}^{3+}$ unit of 9 causes sufficient splitting of the $t_{2 g}$ (in $\left.O_{h}\right)$ set $\left(5 \mathrm{~d}_{x z}, 5 \mathrm{~d}_{y z} \gg\right.$ $\left.5 \mathrm{~d}_{x y}\right)$ that diamagnetism occurs through the configuration $\left(5 \mathrm{~d}_{x y}\right)^{2}$.

Complexes 1-10 are microcrystalline or powder-like, stable in the normal laboratory atmosphere, and soluble only in DMF and DMSO. We had hoped to structurally characterized one or two complexes by singlecrystal X-ray crystallography (working mainly with DMF or $\mathrm{DMF} / \mathrm{MeCN}$ ), but were thwarted on numerous occasions by twinning problems or lack of single crystals. Thus, the characterization of the complexes is based on spectroscopic methods.

\subsection{Electronic spectra}

The band at $335 \mathrm{~nm}$ in the DRS spectrum of $\mathbf{1}$ is assigned to an $\mathrm{O}^{2-} \rightarrow \mathrm{Mo}^{\mathrm{VI}} \mathrm{p}-\mathrm{d}$ LMCT transition and is characteristic of the $\left\{\mathrm{MoO}_{2}\right\}^{2+}$ moiety [11] in octahedral complexes. The transition appears at $337 \mathrm{~nm}$ as a shoulder in solution (DMSO). The DRS spectrum of $\mathbf{3}$ is indicative of its lowspin octahedral structure. The ground term is ${ }^{1} A_{1 g}$ and the two spin-allowed transitions to ${ }^{1} T_{1 g}$ and ${ }^{1} T_{2 g}$ are observed at 565 and $420 \mathrm{~nm}$, respectively [12]; the corresponding bands in DMSO are at 560 and $430 \mathrm{~nm}$. The DRS spectra of the $\mathrm{Rh}$ (III) complexes 4 and 6 both exhibit bands at $\sim 470$ and $\sim 380 \mathrm{~nm}$; the spectra resemble those of other six-coordinate $\mathrm{Rh}$ (III) compounds and the bands are assigned as transitions from the ${ }^{1} A_{1 g}$ ground state to the ${ }^{1} T_{1 g}$ and ${ }^{1} T_{2 g}$ upper states in octahedral symmetry in decreasing order of wavelength [12]. The lower wavelength band may also have a chargetransfer character. Both complexes exhibit an additional band in the blue region of the spectrum $(\sim 520 \mathrm{~nm})$ which is responsible for their red-brown colors; a possible origin of this band is the singlet-triplet, spin-forbidden transition ${ }^{1} A_{1 g} \rightarrow{ }^{3} T_{2 g}$ [12]. The spectrum of the $\operatorname{Ir}(\mathrm{III})$ complex $\mathbf{5}$ shows two bands at 380 and $335 \mathrm{~nm}$, which have a similar interpretation; the ${ }^{1} A_{1 g} \rightarrow{ }^{3} T_{2 g}$ transition is not observed. A weak shoulder in the spectrum of 9 is assigned to the ${ }^{3} T_{1 g}(F) \rightarrow{ }^{3} T_{2 g}$ transition in a $\mathrm{d}^{2}$ octahedral environment, while an intense band at $375 \mathrm{~nm}$ most probably has an LMCT origin [12]. The ligand-field spectra of 7 and 8 are typical of a square planar environment around $\mathrm{pd}^{\mathrm{II}}$ with a mixed N,O-ligation; the bands at 480,375 , and $330 \mathrm{~nm}$ are assigned [12] to the ${ }^{1} A_{1 g} \rightarrow{ }^{1} A_{2 g},{ }^{1} A_{1 g} \rightarrow{ }^{1} E_{g}$, and ${ }^{1} A_{1 g} \rightarrow{ }^{1} B_{1 g}$ transitions, respectively, under $D_{4 h}$ symmetry. The spectra in DMSO exhibit only two bands at 480 and $330 \mathrm{~nm}$.

\subsection{NMR studies}

Diagnostic ${ }^{1} \mathrm{H}$ NMR assignments (in DMSO- $\mathrm{d}_{6}$ ) for representative complexes are presented in Table 1 . The study was based on comparison with the data obtained for diamagnetic complexes with similar ligands $[7,13,14]$. In all the spectra 
studied, the integration ratio of the signals is consistent with the assignments.

The spectrum of LH exhibits two singlets at $\delta 6.07$ and 6.18 assigned to the $-\mathrm{N}(4) \mathrm{H}_{2} /-\mathrm{N}(6) \mathrm{H}_{2}$ (for the numbering scheme see Scheme 2) amino hydrogens, respectively, and two relatively broad singlets at $\delta 7.43$ and 9.13 due to the amide and hydroxyl protons $-\mathrm{N}(1) \mathrm{H}-$ and $-\mathrm{O}(5) \mathrm{H}$, respectively. The appearance of these four peaks is consistent with the exclusive presence of the thione form of $\mathrm{LH}$ (Scheme 2) in solution. The proton of the hydroxyl group is not observed in the spectra of the complexes confirming its deprotonation and coordination to the metal ions. In the spectra of $\mathbf{1}, \mathbf{3}, \mathbf{4}$, and $\mathbf{6 - 8}$, the $-\mathrm{N}(1) \mathrm{H}$ - signal undergoes a marginal shift to indicate the noninvolvement of this group in coordination; a relatively large downfield shift would be expected if coordination had occurred. In the same spectra, two signals appear for $-\mathrm{NH}_{2}$ protons, as expected. The most pronounced variation in chemical shift is the downfield shift of one signal. Since more specific assignments of these two signals seem impossible, it is difficult to conclude which amino nitrogen is coordinated. NMR evidence for the presence of thione -thiol tautomerism in the metal complexes in solution was not found.

The ${ }^{1} \mathrm{H}$ NMR spectrum of 4 confirms that the three N,Obidentate (vide infra) ligands are equivalent ( $C_{3}$ symmetry), and, therefore, the complex has the fac stereochemistry [15].

The spectrum of $\mathbf{8}$ is indicative of the presence of one solution species containing coordinated phen, consisting of four resonances [16]. Assignments are as follows (the numbers in parentheses are the positions of the protons in the classical numbering scheme of 1,10-phenanthroline; $\mathrm{s}=$ singlet, $\mathrm{dd}=$ doublet of doublets $): 9.15 \mathrm{dd}(2 \mathrm{H} ; 2,9)$, $8.53 \mathrm{dd}(2 \mathrm{H} ; 4,7), 8.00 \mathrm{~s}(2 \mathrm{H} ; 5,6)$, and $7.81 \mathrm{q}(2 \mathrm{H} ; 3,8)$. Considerable downfield coordination shifts, $\Delta \delta\left(\mathrm{H}_{l}\right)\left[\Delta \delta\left(\mathrm{H}_{l}\right)=\right.$ $\left.\delta\left(\mathrm{H}_{l}\right)_{\text {complex }}-\delta\left(\mathrm{H}_{l}\right)_{\text {free phen }}\right]$, are observed for all resonances, their values being $0.16,0.27,0.31$, and 0.19 for the protons of the positions $(2,9),(4,7),(5,6)$, and $(3,8)$, respectively. These shifts are characteristic of coordinated phen [16].

The ${ }^{31} \mathrm{P}\left\{{ }^{1} \mathrm{H}\right\}$ NMR spectrum of the $\mathrm{Re}(\mathrm{V})$ complex 9 in DMSO- $\mathrm{d}_{6}$ consists of a sharp singlet at $\delta-16.89$, a value which is typical for $\mathrm{PPh}_{3}$-containing oxorhenium(V) species [17].

\subsection{Vibrational spectra}

Tentative assignments of selected IR ligand bands for complexes 1-10 and free LH are listed in Table 2. The assignments have been given by studying literature reports $[3,13,14]$, comparing the spectrum of $\mathrm{LH}$ with the spectra of the complexes and by performing deuterium isotopic substitution experiments in few cases. As a general remark, we must emphasize that some stretching and deformation modes are coupled, so that the proposed assignments should be regarded as approximate descriptions of the vibrations.

In the $v(\mathrm{OH})_{\text {water }}$ region, the spectra of complexes 1-3 show one medium-intensity band at $\sim 3420 \mathrm{~cm}^{-1}$ attributed to the presence of coordinated water [13]. The same spectra exhibit, in addition to the relatively sharp band of coordinated water, a weaker broad continuous absorption covering
TABle 1: Diagnostic ${ }^{1} \mathrm{H}$ NMR $(\delta, \mathrm{ppm})^{\mathrm{a}}$ spectral data for LH and the representative complexes $\mathbf{1}, \mathbf{3}, \mathbf{4}$, and 6-8 in DMSO- $\mathrm{d}_{6}$.

\begin{tabular}{lccc}
\hline Compound & $-\mathrm{N}(1) \mathrm{H}-$ & $-\mathrm{N}(4) \mathrm{H}_{2} /-\mathrm{N}(6) \mathrm{H}_{2}$ & $-\mathrm{O}(5) \mathrm{H}$ \\
\hline $\mathrm{LH}$ & 7.43 & $6.07,6.18$ & 9.13 \\
$\mathbf{1}$ & 7.57 & $6.18,6.55$ & - \\
$\mathbf{3}$ & 7.49 & $6.14,6.47$ & - \\
$\mathbf{4}$ & 7.44 & $6.20,6.49$ & - \\
$\mathbf{6}$ & $\mathrm{b}$ & $6.11,6.47$ & - \\
$\mathbf{7}$ & 7.47 & $6.17,6.48$ & - \\
$\mathbf{8}$ & 7.39 & $6.08,6.46$ & - \\
\hline
\end{tabular}

${ }^{a}$ The spectra were run 10-15 min after dissolution.

b Obscured by the signals of the aromatic protons.

the $3400-3200 \mathrm{~cm}^{-1}$ region; this is apparently due to the simultaneous presence of crystal and coordinated water in these complexes [14]. In the spectra of 4-8, a medium broad absorption indicates the presence of exclusively crystal (lattice) water.

The absence of an IR or Raman band at $\sim 2600 \mathrm{~cm}^{-1}$ in the spectrum of free LH suggests that the ligand exists in its thione form (see Scheme 2) [18]. This is corroborated by the appearance of the medium $v\left(\mathrm{C}=\mathrm{S}\right.$ ) band at $1177 \mathrm{~cm}^{-1}$ (this vibration appears as a strong peak at $1160 \mathrm{~cm}^{-1}$ in the Raman spectrum) and the strong IR $v(\mathrm{~N}-\mathrm{H})$ band at $2970 \mathrm{~cm}^{-1}$ (this vibration appears as a medium peak at $\sim 3000 \mathrm{~cm}^{-1}$ in the Raman spectrum); the broadness and low frequency of the latter IR band are both indicative of the involvement of the $-\mathrm{NH}$ - group in strong hydrogen bonding.

The medium IR band at $3305 \mathrm{~cm}^{-1}$ in the spectrum of free $\mathrm{LH}$ is assigned to the $v(\mathrm{OH})$ vibration. This band does not appear in the spectra of the complexes indicating deprotonation of the $-\mathrm{OH}$ group and suggesting coordination of the resulting, negatively charged oxygen atom. The absence of large systematic shifts of the $\delta(\mathrm{N}-\mathrm{H}), \delta(\mathrm{NH}), v(\mathrm{C}=\mathrm{N})$, $v\left(\mathrm{C}_{2}-\mathrm{N}_{1}\right) / v\left(\mathrm{C}_{2}-\mathrm{N}_{3}\right)$, and $v(\mathrm{C}=\mathrm{S})$ bands in the spectra of the complexes implies that there is no interaction between the ring nitrogen atoms or the exocyclic sulfur atom and the metal ions. The $v_{\mathrm{as}}\left(\mathrm{NH}_{2}\right)$ and $v_{\mathrm{s}}\left(\mathrm{NH}_{2}\right)$ bands are doubled in the spectra of the complexes. One band for each mode appears at almost the same wavenumber compared with the corresponding band in the spectrum of free LH, whereas the other band of each pair is significantly shifted to lower wavenumbers. This fact is a strong evidence for the presence of one coordinated and one "free" (i.e., uncoordinated) amino group per $\mathrm{L}^{-}$in the complexes [7].

The presence of coordinated $\mathrm{PPh}_{3}$ groups in $\mathbf{6}$ and 9 is manifested by the strong IR bands at $\sim 1100$ and $\sim 750 \mathrm{~cm}^{-1}$, attributed to the $v(\mathrm{P}-\mathrm{C})$ and $\delta(\mathrm{CCH})$ vibrations, respectively [17]; the former band overlaps with the $\mathrm{ClO}_{4}{ }^{-}$stetching vibration in the spectrum of the $\mathrm{Rh}$ (III) complex 6 . In the spectrum of 8 , the bands at $1627,1591,1510,1485$, and $1423 \mathrm{~cm}^{-1}$ are due to the phen stretching vibrations [16]; these bands are at higher wavenumbers compared with the free phen indicating chelation. The bands at 854, 841, 743, and $725 \mathrm{~cm}^{-1}$ are assigned to the $\gamma(\mathrm{CH})$ vibrations of the coordinated phen [16]. 
TABLe 2: Diagnostic ligand IR bands $\left(\mathrm{cm}^{-1}\right)$ for LH and complexes 1-10.

\begin{tabular}{|c|c|c|c|c|c|c|c|}
\hline Compound & $v_{\mathrm{as}}\left(\mathrm{NH}_{2}\right)^{\mathrm{a}}$ & $v_{\mathrm{s}}\left(\mathrm{NH}_{2}\right)$ & $v(\mathrm{~N}-\mathrm{H})$ & $v(\mathrm{C}=\mathrm{N}), v(\mathrm{C}=\mathrm{C})$ & $v\left(\mathrm{C}_{2}-\mathrm{N}_{1}\right), v\left(\mathrm{C}_{2}-\mathrm{N}_{3}\right)$ & $\delta(\mathrm{NH})$ & $v(\mathrm{C}=\mathrm{S})$ \\
\hline $\mathrm{LH}$ & 3390 & 3185 & 2970 & 1652 & 1652 & 1455 & 1177 \\
\hline 1 & 3377,3330 & 3180,3156 & 3005 & 1631 & 1553 & 1460 & 1155 \\
\hline 2 & 3388,3356 & 3188,3160 & 3000 & 1633 & 1556 & 1465 & 1170 \\
\hline 3 & 3399,3343 & 3180,3079 & 3010 & 1632 & 1558 & 1464 & 1157 \\
\hline 4 & 3400,3320 & 3160,3105 & 3005 & 1642 & 1560 & 1460 & 1170 \\
\hline 5 & 3387,3320 & 3166,3110 & 3010 & 1635 & 1556 & 1455 & 1177 \\
\hline 6 & 3380,3357 & 3170,3095 & 3015 & 1641 & $1552^{\mathrm{b}}$ & $1443^{\mathrm{b}}$ & 1176 \\
\hline 7 & 3395,3357 & 3164,3098 & 3010 & 1646 & 1550 & 1446 & 1170 \\
\hline 8 & 3397,3360 & 3165,3100 & 3015 & 1640 & 1553 & 1450 & 1176 \\
\hline 9 & 3400,3355 & 3155,3105 & 3012 & 1639 & $1555^{\mathrm{b}}$ & $1460^{\mathrm{b}}$ & 1170 \\
\hline 10 & 3405,3324 & 3180,3100 & 3010 & 1641 & 1558 & 1462 & 1164 \\
\hline
\end{tabular}

${ }^{\text {a }}$ Overlapping with the $v(\mathrm{OH})_{\text {water }}$ band in the spectra of $\mathbf{1 - 8}$.

b Overlapping with phenyl stretching vibrations of the coordinated $\mathrm{PPh}_{3}$ ligands.

TABle 3: Diameters ( $\mathrm{mm}$ ) of growth inhibitions zones for the antibacterial activity of LH and complexes 1, 4, 7, and 8.

\begin{tabular}{lcccccccc}
\hline \multirow{2}{*}{ Compound } & \multicolumn{4}{c}{ S. aureus $\left(\mathrm{mg} / \mathrm{cm}^{3}\right)^{\mathrm{a}}$} & \multicolumn{4}{c}{ P. aeruginosa $\left(\mathrm{mg} / \mathrm{cm}^{3}\right)^{\mathrm{a}}$} \\
& 10 & 20 & 50 & 100 & 10 & 20 & 50 & 100 \\
\hline $\mathrm{LH}$ & 5 & 11 & 28 & 58 & 4 & 10 & 30 & 55 \\
$\mathbf{8}$ & 13 & 22 & 47 & 99 & 10 & 17 & 41 & 83 \\
$\mathbf{7}$ & 10 & 17 & 42 & 86 & 9 & 14 & 39 & 77 \\
$\mathbf{4}$ & 8 & 13 & 29 & 49 & 7 & 13 & 30 & 44 \\
$\mathbf{1}$ & 10 & 19 & 43 & 80 & 7 & 13 & 32 & 61 \\
\hline
\end{tabular}

${ }^{\mathrm{a}} \mathrm{mg} / \mathrm{cm}^{3}$ represents the concentration of the reagent in the gel.

TABle 4: Diameters $(\mathrm{mm})$ of growth inhibition zones for the antifungal activity of LH and complexes 1, 4, 7, and 8 .

\begin{tabular}{lcccccccc}
\hline \multirow{2}{*}{ Compound } & \multicolumn{3}{c}{ A. niger $\left(\mathrm{mg} / \mathrm{cm}^{3}\right)^{\mathrm{a}}$} & \multicolumn{4}{c}{ C. albicans $\left(\mathrm{mg} / \mathrm{cm}^{3}\right)^{\mathrm{a}}$} \\
& 10 & 20 & 50 & 100 & 10 & 20 & 50 & 100 \\
\hline LH & 5 & 12 & 23 & 44 & 6 & 9 & 34 & 55 \\
$\mathbf{8}$ & 15 & 21 & 43 & 91 & 13 & 19 & 44 & 89 \\
$\mathbf{7}$ & 10 & 17 & 40 & 79 & 9 & 16 & 38 & 68 \\
$\mathbf{4}$ & 0 & 0 & 0 & 0 & 6 & 11 & 21 & 37 \\
$\mathbf{1}$ & 6 & 15 & 31 & 63 & 7 & 16 & 33 & 68 \\
Nystatin $^{\mathrm{b}}$ & 17 & 19 & 36 & 65 & 20 & 26 & 42 & 79
\end{tabular}

${ }^{\mathrm{a}} \mathrm{mg} / \mathrm{cm}^{3}$ represents the concentration of the reagent in the gel.

${ }^{b}$ A currently prescribed antifungal drug.

The vibrational spectra of the inorganic "parts" of complexes 1, 2, 6, 9, and 10 are also diagnostic. The IR spectrum of 6 exhibits a strong band at $\sim 1100$ and a medium band at $624 \mathrm{~cm}^{-1}$ due to the $v_{3}\left(F_{2}\right)$ and $v_{4}\left(F_{2}\right)$ modes of the uncoordinated $T_{\mathrm{d}} \mathrm{ClO}_{4}{ }^{-}$ion [19], respectively, the former having also $v(\mathrm{P}-\mathrm{C})$ character [17]. In the $1000-750 \mathrm{~cm}^{-1}$ region, the spectra of $\mathbf{1}$ and $\mathbf{2}$ show bands characteristic of the cis- $\mathrm{MO}_{2}{ }^{2+}$ units and the $\left\{\mathrm{O}_{2} \mathrm{M}-\mathrm{O}-\mathrm{MO}_{2}\right\}^{2+}$ core $(\mathrm{M}=\mathrm{Mo}$, W) $[20,21]$. The IR bands at 930 and $912 \mathrm{~cm}^{-1}$ in 1 are assigned to the $v_{\mathrm{s}}\left(\mathrm{MoO}_{2}\right)$ and $v_{\mathrm{as}}\left(\mathrm{MoO}_{2}\right)$ modes, respectively $[19,20]$; the corresponding Raman bands appear at 910 and

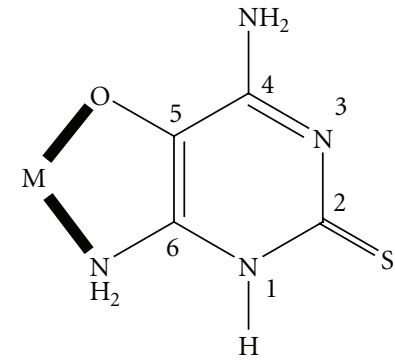

Scheme 3: The proposed coordination mode of the anionic ligand $\mathrm{L}^{-}$in complexes 1-10; $\mathrm{M}=$ metal ion.

$896 \mathrm{~cm}^{-1}$. As expected [19], the symmetric mode is weak in the IR spectrum and strong in the Raman spectrum, while the opposite applies for the asymmetric mode. The appearance of two stretching bands is indicative of the cis configuration [19]. The strong IR band at $745 \mathrm{~cm}^{-1}$ is assigned to the $v_{\mathrm{as}}(\mathrm{Mo}-\mathrm{O}-\mathrm{Mo})$ mode [20], indicating the presence of a $\mu$-O $\mathrm{O}^{2-}$ group. The $v_{\mathrm{s}}\left(\mathrm{WO}_{2}\right), v_{\mathrm{as}}\left(\mathrm{WO}_{2}\right)$, and $v_{\mathrm{as}}(\mathrm{W}-\mathrm{O}-\mathrm{W})$ bands appear at 945,922 , and $755 \mathrm{~cm}^{-1}$, respectively, in the IR spectrum of complex 2 [19, 21]; the $v_{\mathrm{s}}\left(\mathrm{WO}_{2}\right)$ and $v_{\mathrm{as}}\left(\mathrm{WO}_{2}\right)$ Raman bands are at 940 and $917 \mathrm{~cm}^{-1}$, respectively. The $v_{\mathrm{s}}\left(\mathrm{WO}_{2}\right)$ and $v_{\text {as }}\left(\mathrm{WO}_{2}\right)$ modes are at higher wavenumbers when compared to those of the analogous $\mathrm{Mo}(\mathrm{VI})$ complex 1, suggesting [21] that the cis$\mathrm{WO}_{2}{ }^{2+}$ group has some "triple" bond character [21]. In the spectra of 9 , the band attributed to $\nu(\mathrm{Re}=\mathrm{O})$ appears at 956 (IR) and 968 (Raman) $\mathrm{cm}^{-1}[17,19]$. The IR spectrum of the uranyl complex 10 exhibits only one $\mathrm{U}=\mathrm{O}$ stretching band, that is, $v_{\mathrm{as}}\left(\mathrm{UO}_{2}\right)$, at $940 \mathrm{~cm}^{-1}$ (not observed in the Raman spectrum) indicating its linear transdioxo configuration [19]. The $v_{s}\left(\mathrm{UO}_{2}\right)$ mode appears as a strong Raman peak at $905 \mathrm{~cm}^{-1}$, and, as expected, the corresponding IR band is very weak. The bands at 345 and $298 \mathrm{~cm}^{-1}$ in the far-IR spectrum of 7 are assigned to the $v\left(\mathrm{Pd}-\mathrm{NH}_{2}\right)$ and $v(\mathrm{Pd}-$ $\mathrm{O})$ vibrations, respectively. The appearance of one band for 


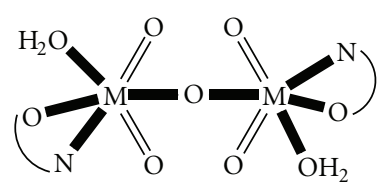

1,2

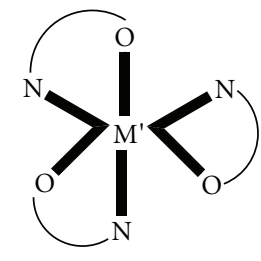

4,5

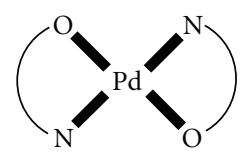

7

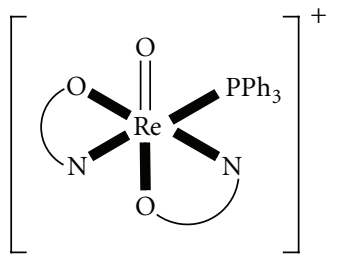

9

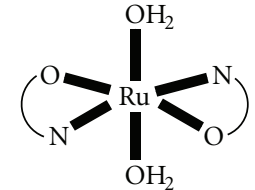

3

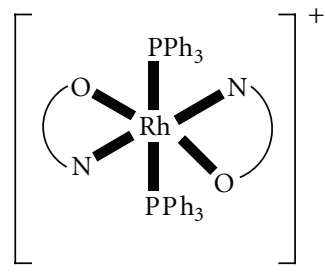

6
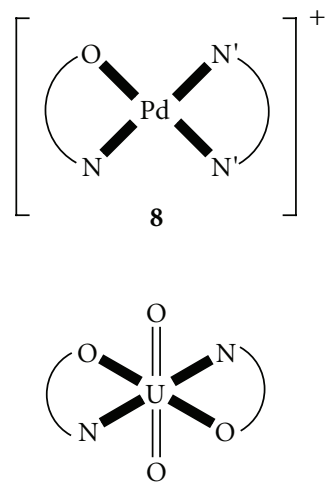

10
Figure 1: Schematic structures proposed for the neutral complexes $1-5,7,10$ and for the cations of complexes 6, 8, 9. Lattice $\mathrm{H}_{2} \mathrm{O}$ molecules and counterions have been omitted for clarity. However, $\widehat{\mathrm{NO}}$ and $\mathrm{N}^{\prime} \mathrm{N}^{\prime}$ represent the ligands $\mathrm{L}^{-}$and phen, respectively. The $\mathrm{N}$ and $\mathrm{O}$ donor atoms of $\mathrm{L}^{-}$are the amino nitrogen of the position 6 (most probably) and the deprotonated oxygen of the position 5 of the pyrimidine ring; $\mathrm{M}=\mathrm{Mo}, \mathrm{W} ; \mathrm{M}^{\prime}=\mathrm{Rh}$, Ir.

each mode ( $B_{3 u}$ and $B_{2 u}$ under $\left.D_{2 h}\right)$ is consistent with a trans structure [19].

\subsection{Antimicrobial activity studies}

The free ligand $\mathrm{LH}$ and its complexes 1, 4, 7, and 8 were assayed in vitro for antimicrobial activity against two bacterial ( $S$. aureus and $P$. aeruginosa) and two fungal $(A$. niger and $C$. albicans) cultures. The hot plate diffusion method was adopted for the activity measurements [22]. Results are listed in Tables 3 and 4.

In general, the $\mathrm{Pd}(\mathrm{II})$ complexes 7 and $\mathbf{8}$ were found to have higher efficacy than 1, 4, and LH at the measured concentrations. The water-soluble complex $\mathbf{8}$ is the most active against the pathogens studied. It is remarkable that the antifungal activity of $\mathbf{8}$ is comparable with, or even better than, the activity of the antifungal drug nystatin, and this may be due to the simultaneous presence of phen and $\mathrm{L}^{-}$ in the complex. The activity of the Pd(II) complexes 7 and 8 is tentatively attributed to their inhibition of the DNA replication (by interacting with enzyme prosthetic groups and altering the microbial metabolism) and their ability to form hydrogen bonds with the cell wall and cell constituents [23]. The weaker activity of $\mathbf{4}$ is noteworthy; the reason for this is not clear.

\section{CONCLUSIONS}

The M/LH general reaction system fulfilled its promise as a source of interesting complexes. From the overall evidence presented before, it seems that the ligand $\mathrm{L}^{-}$behaves as a bidentate chelate in all the prepared complexes with the deprotonated oxygen and most probably the amino nitrogen of the position 6 of the pyrimidine ring being the donor atoms, see Scheme 3. However, the participation of the amino nitrogen of the position 4 of the ring cannot be ruled out. The nonparticipation of the sulfur atom in coordination in complexes $\mathbf{7}$ and $\mathbf{8}$ may be seen as unusual given the soft character of $\mathrm{Pd}(\mathrm{II})$ in the context of the HSAB concept.

The chelate effect (a stable chelating ring with the participation of the sulfur atom cannot be formed due to the geometry of $\mathrm{L}^{-}$) seems to govern the thermodynamic stability of these complexes. The proposed gross schematic structures for 1-10 are shown in Figure 1. Due to the fact that single-crystal, X-ray crystallographic studies are not available, few structural features (e.g., the symmetric structures of $\mathbf{1 - 3}, \mathbf{6}, \mathbf{7}$, and 10) are tentative. The metal ions adopt octahedral $(\mathbf{1}-\mathbf{6}, \mathbf{9}, \mathbf{1 0})$ or square planar $(\mathbf{7}, \mathbf{8})$ stereochemistries.

Finally, complexes 1, 4, 7, and 8 are new welcome additions in the growing family of metal complexes with antimicrobial activity.

The results described in this report represent the initial study of the coordination chemistry of LH and the biological activity of its complexes. Further studies with 3d-metal ions are in progress.

\section{ACKNOWLEDGMENTS}

The authors thank Dr. Constantinos Milios (University of Edinburgh, UK) and Professor H. O. Desseyn (University of Antwerp, Belgium) for providing them with the ${ }^{31} \mathrm{P}\left\{{ }^{1} \mathrm{H}\right\}$ NMR spectrum of 9 and far-IR/Raman spectra of some complexes.

\section{REFERENCES}

[1] S. K. Hadjikakou, M. A. Demertzis, M. Kubicki, and D. Kovala-Demertzi, "Organotin adducts with pyrimidinethione: crystal structure of dimethyldi(pyrimidine-2-thiolato)tin(IV) and diphenyldi(pyrimidine-2-thiolato)tin(IV)," Applied Organometallic Chemistry, vol. 14, no. 11, pp. 727-734, 2000.

[2] C.-L. Ma, Y. Shi, Q.-F. Zhang, and Q. Jiang, "Syntheses, characterization and crystal structures of diorganotin compounds with 2-mercaptopyrimidine and 4-amino-2mercaptopyrimidine," Polyhedron, vol. 24, no. 10, pp. 11091116, 2005. 
[3] M. A. Romero-Molina, M. D. Gutierrez-Valero, R. LopezGarzon, J. M. Salas-Peregrin, M. I. Arriortua, and F. J. Zuñiga, "Studies on pyrimidine derivative complexes: spectroscopy, thermal behaviour and crystal structure of $\mu$-dichloro- $\mu$ sulphur-chloro(4,6-diamino-1,2-dihydro-2-thiopyrimidine$N^{3}, S^{2}$ )cadmium(II) monohydrate," Inorganica Chimica Acta, vol. 136, no. 2, pp. 87-92, 1987.

[4] E. Barea, J. A. R. Navarro, J. M. Salas, N. Masciocchi, S. Galli, and A. Sironi, " $\left[\mathrm{Cu}(4 \text {-oxopyrimidinate })_{2} \cdot n \mathrm{H}_{2} \mathrm{O}\right]_{\infty}$ : a robust sodalite type metal-organic framework exhibiting a rich hostguest chemistry," Polyhedron, vol. 22, no. 22, pp. 3051-3057, 2003.

[5] N. Masciocchi, S. Galli, A. Sironi, et al., "Rich structural and magnetic chemistry of cobalt(II) pyrimidin-2-olate and pyrimidin-4-olate complexes. Synthesis, X-ray powder diffraction studies, and thermal behavior," Chemistry of Materials, vol. 15, no. 11, pp. 2153-2160, 2003.

[6] Z. Qin, M. C. Jennings, and R. J. Puddephatt, "Molecular triangle of palladium(II) and its anion binding properties," Inorganic Chemistry, vol. 41, no. 15, pp. 3967-3974, 2002.

[7] S. I. Mostafa, M. A. Kabil, E. M. Saad, and A. A. El-Asmy, "Ligational and analytical applications of a uracil derivative toward some transition metal ions," Journal of Coordination Chemistry, vol. 59, no. 3, pp. 279-293, 2006.

[8] N. P. Johnson, C. J. L. Lock, and G. Wilkinson, "Amine, phosphine, arsine, and stibine complexes of rhenium-(III), (IV), and -(V)," Journal of the Chemical Society, pp. 10541066, 1964.

[9] F. A. Cotton, G. Wilkinson, C. A. Murillo, and M. Bochmann, Advanced Inorganic Chemistry, John Wiley \& Sons, New York, NY, USA, 6th edition, 1999.

[10] W. J. Geary, "The use of conductivity measurements in organic solvents for the characterisation of coordination compounds," Coordination Chemistry Reviews, vol. 7, no. 1, pp. 81-122, 1971.

[11] F. W. Moore and R. E. Rice, "Physicochemical and spectral properties of octahedral dioxomolybdenum(VI) complexes," Inorganic Chemistry, vol. 7, no. 12, pp. 2510-2514, 1968.

[12] A. B. P. Lever, Inorganic Electronic Spectroscopy, Elsevier, Amsterdam, The Netherlands, 2nd edition, 1984.

[13] N. Lalioti, C. P. Raptopoulou, A. Terzis, A. Panagiotopoulos, S. P. Perlepes, and E. Manessi-Zoupa, "New metal-binding modes for 5-aminoorotic acid: preparation, characterization and crystal structures of zinc(II) complexes," Journal of the Chemical Society, Dalton Transactions, no. 8, pp. 1327-1334, 1998.

[14] S. P. Perlepes, V. Lazaridou, B. Sankhla, and J. M. Tsangaris, "Synthesis, physical properties and spectroscopic studies of isoorotato, 5-aminoorotato and 2-thioorotato lanthanide(III) complexes," Bulletin de la Société Chimique de France, vol. 127, pp. 597-608, 1990.

[15] J. Romero, M. L. Durán, A. Rodriguez, et al., "Electrochemical synthesis and characterization of indium pyrimidine2-thiolate complexes. Molecular structure of tris (pyrimidine-2-thiolato) indium (III) and tris [(5-ethyl4,6-dimethyl)pyrimidine-2-thiolato]indium(III)," Inorganica Chimica Acta, vol. 274, no. 2, pp. 131-136, 1998.

[16] A. K. Boudalis, V. Nastopoulos, S. P. Perlepes, C. P. Raptopoulou, and A. Terzis, "Reactions of 2,2'-bipyridine (bpy) and 1,10-phenanthroline (phen) with yttrium(III) nitrate: preparation, X-ray crystal structures and spectroscopic characterization of the bis-bpy and bis-phen complexes," Transition Metal Chemistry, vol. 26, no. 3, pp. 276-281, 2001.
[17] A. G. de A. Fernandes, P. I. da S. Maia, E. J. de Souza, et al., "Rhenium chelate complexes with maltolate or kojate," Polyhedron, vol. 27, no. 13, pp. 2983-2989, 2008.

[18] E. López-Torres and M. A. Mendiola, "Complexes of a triazine-3-thione ligand with divalent metals: crystal structure of $\left[\mathrm{CdL}_{2} \mathrm{DMF}\right]_{2} \cdot 2 \mathrm{DMF} \cdot 1 / 4 \mathrm{H}_{2} \mathrm{O}$," Polyhedron, vol. 24 , no. 12 , pp. 1435-1444, 2005.

[19] K. Nakamoto, Infrared and Raman Spectra of Inorganic and Coordination Compounds, John Wiley \& Sons, New York, NY, USA, 4th edition, 1986.

[20] Z.-H. Zhou, H.-L. Wan, and K.-R. Tsai, "Syntheses and spectroscopic and structural characterization of molybdenum(VI) citrato monomeric raceme and dimer, $\mathrm{K}_{4}\left[\mathrm{MoO}_{3}\right.$ (cit) $] \cdot 2 \mathrm{H}_{2} \mathrm{O}$ and $\mathrm{K}_{4}\left[\left(\mathrm{MoO}_{2}\right)_{2} \mathrm{O}(\mathrm{Hcit})_{2}\right] \cdot 4 \mathrm{H}_{2} \mathrm{O}$," Inorganic Chemistry, vol. 39, no. 1, pp. 59-64, 2000.

[21] H. Arzoumanian, G. Agrifoglio, M. V. Capparelli, R. Atencio, A. Briceño, and A. Alvarez-Larena, "Synthesis and characterization of thiocyanato and chlorodioxo tungsten(VI) compounds: comparative oxygen atom transfer capability with molybdenum analogs," Inorganica Chimica Acta, vol. 359, no. 1, pp. 81-89, 2006.

[22] C. H. Collins and P. M. Lyne, Microbiological Methods, University Park Press, Baltimore, Md, USA, 1970.

[23] R. P. John, A. Sreekanth, V. Rajakannan, T. A. Ajith, and M. R. P. Kurup, "New copper(II) complexes of 2hydroxyacetophenone $N(4)$-substituted thiosemicarbazones and polypyridyl co-ligands: structural, electrochemical and antimicrobial studies," Polyhedron, vol. 23, no. 16, pp. 2549$2559,2004$. 


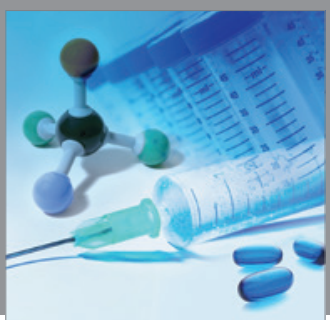

International Journal of

Medicinal Chemistry

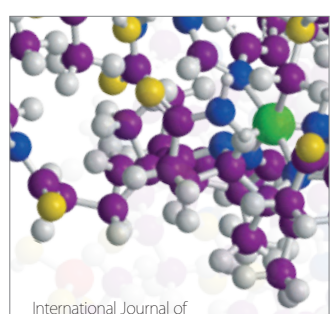

Carbohydrate Chemistry

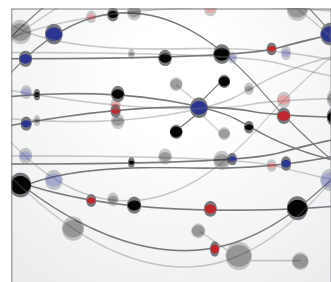

The Scientific World Journal
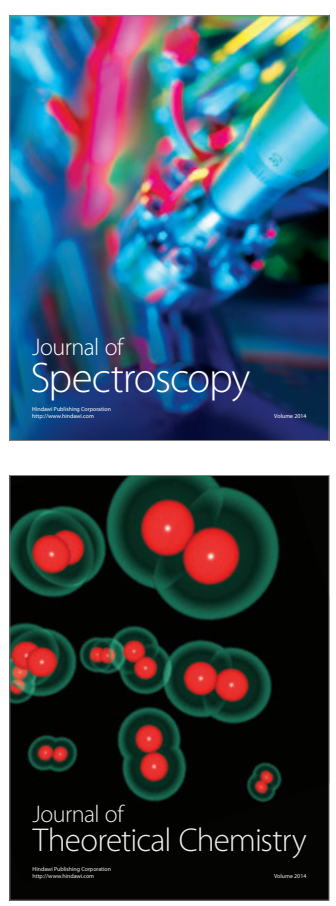
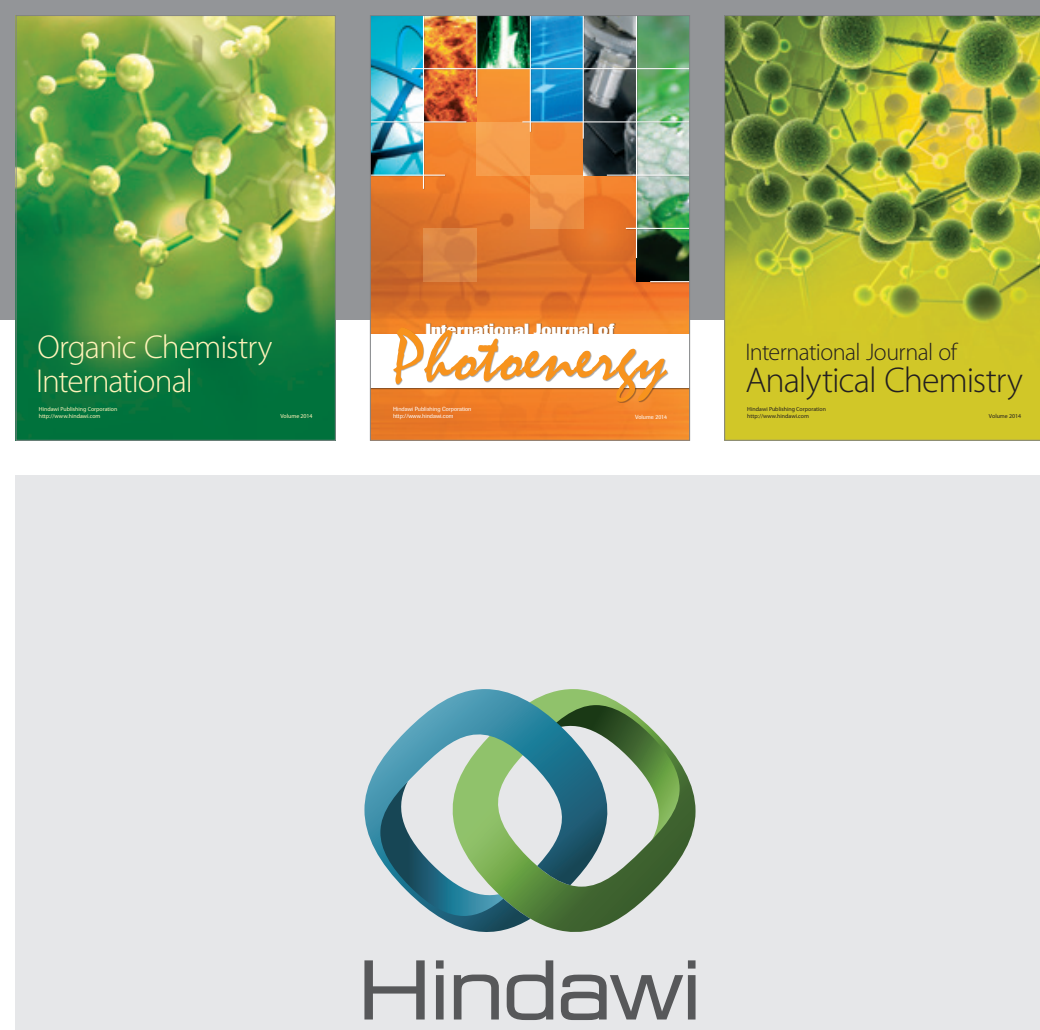

Submit your manuscripts at

http://www.hindawi.com
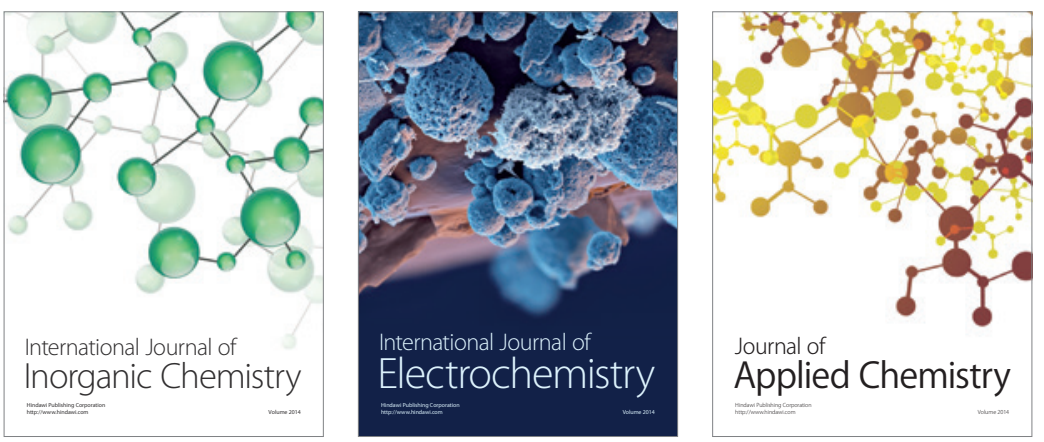

Journal of

Applied Chemistry
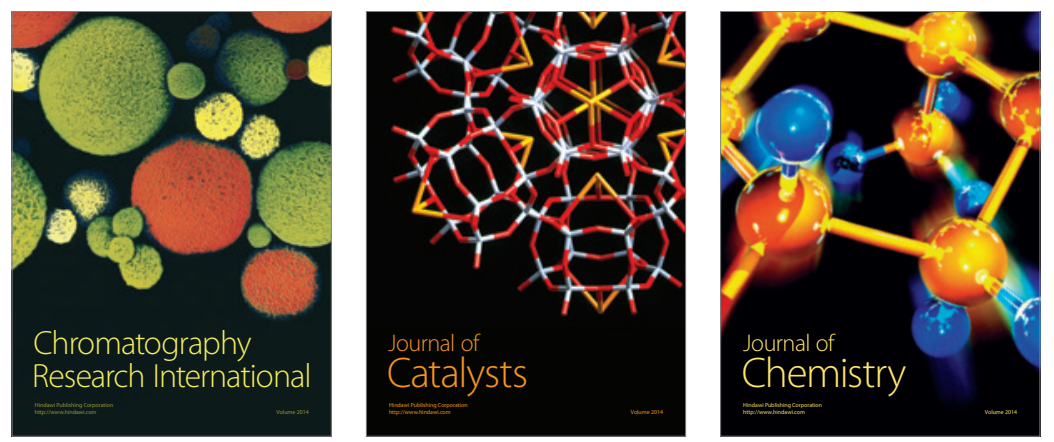
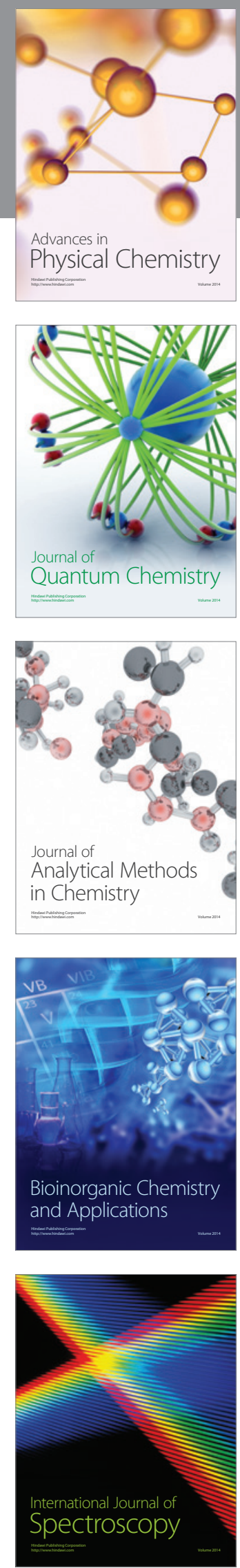